\title{
BIOCHEMICAL IMPLICATIONS OF INSECT MYCOPHAGY
}

\author{
By MICHAEL M. MARTIN \\ Department of Chemistry and Division of Biological Sciences, \\ University of Michigan, Ann Arbor, Michigan 48rog, U.S.A.
}

(Received 22 May 1978)

I. Introduction .

\section{CONTENTS}

II. Arthropod-fungal associations .

(I) Arthropods associated with sporophores

(2) Arthropods in habitats which include fungal mycelium

(3) Insects involved symbiotically with fungi

III. Nutritive characteristics of fungal tissue .

(I) Caloric value

(2) Elemental composition

(3) The macronutrients of fungi

(4) The micronutrients of fungi

(5) Summary .

IV. Digestive and metabolic requirements imposed on mycophagous species by the special characteristics of fungal tissue.

(I) Fungal polysaccharides

(2) Fungal sterols.

(3) Urea and ammonia.

(4) Secondary metabolites

(5) Summary .

V. Acquired digestive enzymes : a windfall of mycophagy

(I) Enzymes active against plant cell-wall polysaccharides

(2) Enzymes active against fungal constituents.

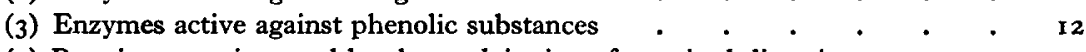

(4) Requirements imposed by the exploitation of acquired digestive enzymes . I3

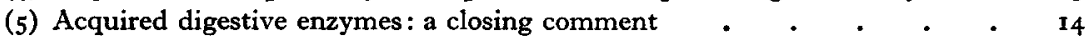

VI. Summary

VII. Acknowledgement

VIII. References

\section{INTRODUCTION}

Many arthropods, especially insects and mites, have established close associations with fungi, and among such species the consumption of fungal tissue (mycophagy) is common. Many species spend major portions of their lives in the fruiting bodies (sporophores or sporocarps) of higher macrofungi and utilize these structures for food and shelter as well as sites for mating and oviposition. Some species occupy habitats such as dead or diseased timber, rotting wood, and decaying plant debris, 
in which they come into close contact with various reproductive and vegetative portions of fungi which permeate these substrates. Many of the species which live in such habitats are known to feed upon fungal hyphae and spores to a varying extent. Still other species have established elaborate symbiotic associations with fungi in which the insects consume the fungus and also foster its growth and dispersal.

It is the purpose of this review to discuss the biochemical implications of mycophagy. It will consider the amounts of the various macro- and micronutrients present in fungi and draw an over-all picture of the nutritive potential of fungal tissue to a consumer. It will then explore some other aspects of fungal composition, such as the nature of the cell wall polysaccharides, the structure of fungal sterols, and the nature of the substances employed for nitrogen storage, which impose special requirements upon the digestive capacities of a consumer. The final section is rather speculative and considers a consequence of mycophagy, namely the acquisition of fungal enzymes, which may have far-reaching biological implications.

Although mycophagy is widespread among insects, the biochemical requirements and consequences of this mode of nutrition have not received the attention they deserve. Indeed, a major impetus for the preparation of this review was the belief that a failure to recognize the many biochemical implications of mycophagy has led to a general lack of appreciation of its full biological significance.

\section{ARTHROPOD-FUNGAL ASSOCIATIONS}

In order to allow the biochemical discussions which follow to be integrated into a biological context, the review begins by describing those circumstances in which mycophagy is a common occurrence. This section also provides references which can serve as useful entrées into the vast literature of insect-fungus associations (Fogel, r975).

\section{(1) Arthropods associated with sporophores}

Fungal sporophores are small habitat units widely scattered in space and time, and their temporal predictability is a major factor influencing the nature and diversity of their associated arthropod faunas. The woody-textured basidiocarps of the Aphyllophorales, which are fairly regular in the timing of their appearance and which may even persist for several years, have much larger and more diverse faunas than the shorter-lived fleshy basidiocarps of the Agaricales (Scheerpeltz \& Höfler, 1948; Benick, 1952; Buxton, 1960). Among the soft-bodied fungi, those which grow on rotting wood and whose seasonal appearance is less dependent upon weather conditions have a richer arthropod fauna than those less predictable species which grow on the forest floor.

Collembola, Coleoptera, Diptera and Acarina are the orders of arthropods most frequently collected from woody fungi, both in number of species and number of individuals (Weiss, r920; Scheerpeltz \& Höfler, 1948; Benick, I952; Rehfous, I955; Graves, I960; Paviour-Smith, I960a; Pielou, r966; Pielou \& Verma, 1968; Matthewman \& Pielou, 197I; Ackerman \& Shenefelt, 1973; Lawrence, 1973). Diptera are 
the predominant inhabitants of the shorter-lived fleshy agarics (Scheerpeltz \& Höfler, 1948; Buxton, 1960), and in polypores with fruiting bodies which last for only two or three weeks (Paviour-Smith, $1960 b$ ).

\section{(2) Arthropods in habitats which include fungal mycelium}

The decomposition of wood occurs mainly through the combined activities of fungi and invertebrates, and a number of studies have described the succession of both the fungal and insect species in dead wood (Ingles, 1933; Savely, 1939; Wallace, 1953; Larkin \& Elbourne, 1964; Elton, I966; Fager, r968). Examination of gut contents of beetles collected from rotting logs revealed that some of the beetles feed on wood, some on fungal hyphae and spores, and still others on a mixture of wood and fungal material (Savely, 1939). Termites constitute another major taxon which routinely encounters fungi while feeding in dead wood (Sands, 1969). Xylophagous (wood-eating) Diptera of the family Tipulidae (Freeman, 1967), and a number of species of mites (Lindquist, 1970, 1975; Moser \& Roton, 1971) also ingest fungal material or mixtures of wood and fungal material. Other habitats in which arthropods encounter fungal tissue are litter, herbivore dung, compost, silage and stored grain.

\section{(3) Insects involved symbiotically with fungi}

Insects are associated with fungi in several spectacular symbiotic relationships which have intrigued biologists for over a century. These systems have presented some of the best opportunities to explore the biochemical aspects of insect-fungus associations. The fungus-growing ants (Wheeler, 1907; Weber, 1972; Boyd \& Martin, I975 $a, b$; Martin, Boyd, Gieselmann \& Silver, 1975) and the fungus-growing termites (Sands, 1969; Heim, 1977; Martin \& Martin, 1978, 1979) both culture fungi on plant material brought into their nests. The fungal material is the primary food of the ants, and a quantitatively minor but essential component of the diet of the termites. The ambrosia beetles (Scolytidae and Platypodidae) are wood-boring beetles of considerable economic importance. The larvae of some species feed exclusively on a symbiotic fungal mycelium which lines the walls of their tunnels and galleries. Larvae of other species, as well as adults of all species, devour both wood and fungus (Francke-Grosmann, 1967; Graham, 1967; Barras \& Perry, 1975). The larvae of the siricid wood wasps also develop in tunnels which are lined with the mycelium of a symbiotic fungus. The larvae of some species depend primarily upon the fungus for food, while others consume wood as well as fungal material (Parkin, 1942; Francke-Grosmann, 1939, 1967; Morgan, 1968). Finally, ship timber worms (Coleoptera: Lymexylidae) feed upon a mixture of wood and a fungus presumed to be a symbiont (Francke-Grosmann, 1967). 


\section{NUTRITIVE CHARACTERISTICS OF FUNGAL TISSUE}

\section{(I) Caloric value}

The caloric content of a number of edible mushrooms has been found to fall in the range $0.1-0.7$ calories/g of fresh weight (Pilat $\&$ Úsak, 1958; Hodgman, Weast, Shankland \& Selby, I959; Proudfit \& Robinson, 196I; Singer, 196r). Fleshy fungal tissue compares favourably with many fruits and vegetables in terms of caloric content, but is less rich in energy than seeds, nuts, or animal tissue.

\section{(2) Elemental composition}

Carbon content is generally between 40 and $50 \%$ of the dry weight of fungal tissue, and is relatively unaffected by the conditions of growth (Whitaker, 195I; Cochrane, 1958; Lilly, 1965). The nitrogen content of fungal tissue is highly variable, depending upon species, age, type of tissue and the nitrogen content of the medium or substrate supporting growth (Fitteck, 1929; Foster, 1949; Cochrane, 1958; Lilly, 1965). For a given fungus, the vegetative mycelium and the sporophore generally have comparable levels of nitrogen while the spores have somewhat higher levels. The nitrogen content of fungal mycelium generally ranges from $\mathrm{I}$ to $7 \%$ (dry weight), but may be as low as $0.23 \%$ in some fungi growing on wood, which is a substrate with an extraordinarily low nitrogen content and a very high carbon:nitrogen ratio (Cowling \& Merrill, r966). Thus, for the wood-rotting Basidiomycetes Fomes laricis, $F$. fomentarius, and Coriolus (= Polyporus) versicolor, the mycelia contained from 0.23 to $3.27 \%$ nitrogen, the fruiting bodies 0.72 to $\mathrm{I} \cdot 13 \%$, and the spores about $3 \%$ (Merrill \& Cowling, 1966 ). These authors also noted that the nitrogen content varied among different tissues within the sporophore, being lowest in the context and stipe, intermediate in the hymenium, and highest in the sporulating tissue. The nitrogen of hymenial tissue decreased with age.

The ash content of fungi is also variable. Most have $5-10 \%$ ash, but fruiting bodies collected in the field have ash values ranging from $\mathrm{I}$ to $30 \%$ (Cochrane, 1958). The most abundant minerals are phosphorus and potassium (Cochrane, r $95^{8}$; Lilly, 1965). Other mineral constituents are those generally encountered in other types of tissue, i.e. sodium, calcium, magnesium, iron, zinc, manganese, copper, molybdenum, chloride, and sulphur, chiefly in the form of sulphate (Cochrane, r958; Lilly, 1965).

An important point to keep in mind when assessing the role of fungi in a food chain, or the contribution of fungal tissue to the nutrition of a consumer, is the capacity of fungi to concentrate biologically important elements, such as nitrogen or phosphorus, from extremely dilute substrates, such as wood or plant litter (Cowling \& Merrill, 1966; Graham, 1967; Levi \& Cowling, 1969; Stark, 1972; Cromack, Todd \& Monk, 1975; Van Lear \& Goebel, 1976; Rohrmann, 1978). An impressive illustration of the importance of this concentrating capacity is provided by the demonstration by Merrill \& Cowling (1966) that an insect would have to consume $36 \cdot 2 \mathrm{~g}$ of the wood on which the fungus Ganoderma (= Fomes) applanatum was growing in order to obtain the quantity of nitrogen present in $2 \cdot 7 \mathrm{~g}$ of sporophore 
tissue or $1.0 \mathrm{~g}$ of spores. The larval growth rates of the two xylophagous beetles Hylotrupes bajulus (Cerambycidae) (Becker, 1942a) and Anobium punctatum (Anobiidae) (Becker, I942 $b$; Bletchley, I953; Bletchley \& Taylor, 1964) appear to be limited by the low nitrogen levels in wood. Both grow more rapidly in wood in an early stage of decay than in sound wood, and it seems very likely that the greater nutritive value of the decayed wood is due to the presence of fungal mycelium which supplements the meagre quantities of nitrogen present in the wood.

\section{(3) The macronutrients of fungi}

Fungal cells, in common with all cells, consist primarily of water, carbohydrate, protein and lipid. The relative amounts of the major constituents of fungal tissue are extremely variable among species, and highly dependent upon conditions of growth. Although carbohydrate contents ranging from 14 to $75 \%$ (dry weight) have been recorded, carbohydrate constitutes $50 \%$ or more of most fungal tissues examined (Singer, I96I). Structural polysaccharides associated with the cell wall make up the bulk of this carbohydrate. Thus, fungal tissue is a potentially rich source of carbohydrate for any organism possessing the appropriate digestive enzymes to degrade fungal polysaccharides. The nature of fungal polysaccharides and the requirements imposed by their structures upon the digestive capabilities of mycophagous species will be considered further in Section IV.

The second major component of fungal tissue is protein. Most studies report that fungal tissue consists of $20-40 \%$ (dry weight) protein, with a few as high as $60 \%$ (Singer, 196r). The proteins of fungal tissue contain all of the normal amino acids and are not very different from the proteins of green leaves (Thatcher, 1954). It is also pertinent to note the absence from fungi of condensed tannins (Aronson, 1965 ; Bartnicki-Garcia, 1968, I970), substances present in many higher plants, which complex with proteins and thereby reduce their digestibility and availability to a consumer. Fungal tissue also contains free amino acids (Bonnet, 1959; Heinemann \& Casimir, I960; Miller, I961).

Lipid levels are generally low (I-II \%), although higher levels are not uncommon in spores, and can be produced in mycelia under specific culture conditions (Singer, I96I; Cochrane, I958).

Perhaps the best way to convey a general impression of the nature of fungal tissue as a nutrient source is by comparing it with some familiar food items. The carbohydrate, protein and lipid composition of 'mushrooms' recorded by Hodgman et al. (1959) is very similar to that of Brussels sprouts. In fact, the relative amounts of these three major nutrients in fungi are generally rather similar to those in many common vegetables, with 'mushrooms' being a somewhat richer source of protein. Fungal tissue is a richer source of protein and poorer source of carbohydrate than fruits, and is a less concentrated source of all types of the major classes of nutrients than seeds or nuts (Hodgman et al., 1959). In summary, fungal tissue more closely resembles foliage than it does other types of tissues derived from higher plants, such as fruits, seeds, or wood.

Finally, it is worth-while noting the high water content $(75-95 \%)$ of fleshy 
sporophores (Lilly, 1965). Insects which feed upon such structures are clearly provided with an ample supply of water. The sporophores of woody fungi, however, contain less water, while in spores the water content is considerably lower, and depends greatly upon environmental humidity (Cochrane, 1958; Lilly, I965).

\section{(4) The micronutrients of fungi}

The nutritive value of a material is determined as much by its capacity to provide its consumers with critical micronutrients, such as vitamins or hormone precursors, as by its ability to deliver calories or raw material for the construction of new tissue.

Fungal tissue is a good source of choline and the B-vitamins (Bonnet, 1959; Hodgman et al., I959; Miller, 1961), which are well-established dietary requirements of insects (House, I974a). Many insects also require a dietary supply of polyunsaturated fatty acids, especially linoleic acid (House, 1974a). Fungal lipids incorporate significant quantities of polyunsaturated acids, both in the form of triglycerides and as free fatty acids (Cochrane, 1958; Bonnet, 1959; Birkinshaw, 1965).

All insects require a source of sterols for normal growth and reproduction (House, 1974a). Ergosterol is the major sterol of fungi (Cochrane, 1958; Miller, 1961), and it is present in fungal tissues at levels sufficient to satisfy the requirements of insect consumers. The mycelia of 14 species of wood-rotting Basidiomycetes contained $0.017-0.42 \%$ (dry weight) of ergosterol (Milazzo, 1965). In an elegant series of studies, Norris and his co-workers (Kok, Norris \& Chu, 1970; Norris, 1972) have shown that the sterol requirement of the ambrosia beetle, Xyleborus ferrugineus (Scolytidae), is met by the consumption of a symbiotic fungus, Fusarium solani. The metabolic ramifications of the structure of ergosterol will be discussed in more detail in Section IV.

\section{(5) Summary}

The composition of fungal tissue makes it a desirable resource either as a dietary staple which supplies all of the consumer's needs, or as a minor dietary component which provides some particular nutrient missing from the rest of the diet. Fungal tissue should be recognized as a material of high nutritional value to those organisms possessing the appropriate digestive and metabolic capabilities to exploit it.

\section{DIGESTIVE AND METABOLIC REQUIREMENTS IMPOSED ON MYCOPHAGOUS SPECIES BY THE SPECIAL CHARACTERISTICS OF FUNGAL TISSUE}

Although rather similar to foliage in over-all nutritive potential, fungal tissue is actually very different from the tissues of higher plants. Mycophagy is not simply a modification or extension of phytophagy, but rather is a feeding strategy which requires its own particular set of digestive and metabolic capabilities. This section considers some of these requirements, with particular reference to those imposed by the special nature of fungal cell wall polysaccharides and fungal sterols, as well as by the presence of urea and a diverse array of secondary compounds. 


\section{(I) Fungal polysaccharides}

The cell walls of the higher fungi are very different from the cell walls of higher plants. Even the so-called woody fungi are woody only in texture, not in composition. Fungal cell walls are constructed of polysaccharides which do not occur in higher plants. The primary constituents are chitin, a $\beta$ - $(\mathrm{r}, 4)$-polysaccharide derived from $N$-acetylglucosamine, and a mixture of non-cellulosic $\beta$-D- $(\mathrm{I}, 3)$ - and $\beta$-D- $(\mathrm{I}, 6)$-glucans, along with smaller amounts of $\alpha$-D-glucans and heteropolymers containing glucose, mannose, xylose and fucose (Aronson, I965; Bartnicki-Garcia, I968, 1970; Gorin \& Spencer, 1968; Hall, I969). Cellulose, lignin and pectin are unknown from the higher macrofungi which are the primary concern of this review (Aronson, 1965; Bartnicki-Garcia, I968, 1970). Cellulose does occur in the cell walls of some of the lower aquatic fungi, especially among the Oomycetes (Bartnicki-Garcia, I968), and in a few Ascomycetes in the genera Ceratocystis (Ophiostomataceae) and Europhium (Ophiostomataceae) (Jewell, r974). A polygalacturonide, that is, a true pectic substance has been detected in only one fungal material, the sporangia of the Chytridomycete, Allomyces, while polyglucuronides have been detected in the Zygomycete, Mucor rouxii, and in several Deuteromycetes (Bartnicki-Garcia, 1968). In addition to the structural polysaccharides present in the cell walls, fungal cells also contain smaller amounts of glycogen, which serves as a storage polysaccharide (Bracker, I967; Gorin \& Spencer, r968), and in some species among the fleshy Basidiomycetes significant quantities of the non-reducing disaccharide trehalose, and the alcohol, mannitol (Bonnet, I959; Rast, I965; Lewis \& Smith, r967; Kitomoto \& Gruen, 1976).

Whereas cellulases, hemicellulases and pectinases are the enzymes which permit efficient exploitation of plant tissue by phytophagous insects, chitinases and $\beta-(1,3)$ and $\beta$ - $(1,6)$-glucanases are the enzymes which would be crucial to fungus-feeders. The distribution of digestive chitinases in insects has not been extensively explored, although these enzymes have been detected in the gut fluids of several insect groups, including roaches (Waterhouse \& McKellar, 1961; Powning \& Irzykiewicz, I963; Fisk \& Rao, I964), ants (Martin, Gieselmann \& Martin, I973, 1976), and the tenebrionid beetle, Alphitobius diaperinus (Saxena \& Sarin, 1972), as well as in some other invertebrates (Jeuniaux, 1963, 1966). The fact that the moulting process involves the enzymatic degradation of chitin implies that the capacity of the epidermal cells of the integument to produce chitinases is universal in insects. Thus, it is quite possible that chitinases are digestive enzymes of widespread occurrence in insects.

The distribution of $\beta$ - $(x, 3)$ - and $\beta$ - $(\mathrm{x}, 6)$-glucanases in insects is even less thoroughly explored than the occurrence of digestive chitinases. $\beta-(\mathrm{r}, 3)$-Glucanases are known from only two species, the migratory locust Locusta migratoria migratorioides (Acrididae) (Morgan, I975) and the harvesting termite Trinervitermes trinervoides (Nasutitermitinae) (Potts \& Hewitt, 1974). Neither of these species is believed to feed on fungus. There are no records of $\beta$-( 1,6$)$-glucanases from insects.

The efficiency of digestion of fungal cell wall polysaccharides is relevant to the 
role of insects in the dispersal of fungal phytopathogens. Insects which ingest spores may either limit or facilitate the dispersal of the fungus depending upon whether the spores are digested or not.

\section{(2) Fungal sterols}

Fungal sterols, of which ergosterol is the most common, are 28-carbon sterols having a methyl group at the $\mathrm{C}-24$ position of the side chain. For fungal sterols to fulfil an insect's need for sterols they must be transformed into cholesterol derivatives by the removal of the $\mathrm{C}-24$ methyl group. The ability to dealkylate the $\mathrm{C}-24$ position is common in phytophagous species, which are able to transform the common 28- and 29-carbon plant sterols, such as campesterol, brassicasterol, sitosterol and sigmasterol, into cholesterol derivatives by the removal of a methyl or ethyl group from the side chain (Clayton, 1964, 1970; Robbins, Kaplanis, Svoboda \& Thompson, I971). In fact, phytophagous insects are able to dealkylate ergosterol, even though this is not a common plant sterol (Clark \& Bloch, 1959; Clayton, 1964). Clearly then, the capacity to utilize fungal sterols is widespread, even among insects which do not feed upon fungal tissue, and the adoption of mycophagy as a feeding strategy requires no special biochemical capabilities in relation to sterol metabolism.

\section{(3) Urea and ammonia}

Many higher fungi, especially in the families Tricholomataceae and Agaricaceae, accumulate rather large amounts of urea in their sporophores (Cochrane, I958; Bonnet, 1959; Tyler, Benedict \& Stuntz, 1965). Some species consist of over $7.5 \%$ (dry weight) urea (Tyler et al., 1965). It is not known whether the insects which feed upon such fungi are able to utilize the urea as a source of nitrogen for protein synthesis in the manner of a ruminant, or whether the ingested urea is simply carried through the gut and ultimately excreted. The use of dietary urea as a nitrogen source requires its hydrolysis to carbon dioxide and ammonia, a reaction catalysed by urease, followed by the generation of glutamate by the reaction of $\alpha$-ketoglutarate with ammonia, a transformation catalysed by glutamate dehydrogenase. Whereas glutamate dehydrogenase is widely distributed in insects, the occurrence of urease is exceedingly uncommon (Bursell, 1967), having been detected at high levels only in the bruchid beetle, Caryedes brasiliensis, and at lower levels in three other species of beetle (Rosenthal, Janzen \& Dahlman, 1977). Larvae of C. brasiliensis feed upon seeds of a legume rich in the toxic amino acid, L-canavanine, and the urease is involved in the metabolic pathway by which the canavanine is detoxified and converted ultimately to ammonia for utilization as a nitrogen source. No fungus-feeders have been tested for the presence of urease.

Ammonia is another potential source of nitrogen which occurs widely in the fruiting bodies of higher fungi (Stein von Kamienski, 1958; Miller, 196r). It has been shown that larvae of the blowfly Calliphora vicina (Calliphoridae) can incorporate dietary ammonia into protein (Sedee, 1958). It is not known whether any mycophagous species have this capacity. 


\section{(4) Secondary metabolites}

A wide variety of secondary metabolites, including polyenes, polyacetylenes, terpenes, furans, pyrones, phenols, quinones, melanins, complex nitrogen heterocyclics and peptides occur in fungi (Miller, I96I ; Birkinshaw, 1965; Arpin \& Fiasson, 197I). Many of these substances are surely potentially harmful to any insects which may consume them, and their presence clearly presents a challenge to the capacity of a consumer to detoxify them. For those insects which have evolved mechanisms to counter the deleterious effects of such noxious secondary metabolites, and which are specialized fungus-feeders, these same substances may serve as attractants, or as stimulants to feeding or oviposition. Further studies on the mediation of the interaction of fruiting bodies and their arthropod visitors by the various secondary metabolites present would doubtless contribute greatly to an understanding of host preferences among mycophagous species.

\section{(5) Summary}

This Section has identified several features of fungal tissues which have clear-cut biochemical implications for organisms feeding upon them. In particular, it has emphasized that efficient exploitation of the caloric potential of fungal tissue requires the capacity to digest the chitin and the non-cellulosic $\beta$ - $(1,3)-$ and $\beta$ - $(1,6)$-glucans which constitute the bulk of the fungal cell-wall polysaccharides. It was also noted that full access to the nitrogen content of many fleshy fungi requires the capacity to utilize urea as a nitrogen source, a capacity that depends upon the presence of urease. Finally, it was noted that fungi produce a wide variety of substances which may serve as chemical defences against consumers, thus confronting the detoxification mechanisms of mycophagous insects with a considerable challenge. Throughout this Section the discussion has emphasized the many deficiencies in our current knowledge of the biochemical correlates and consequences of feeding on fungal tissue.

\section{ACQUIRED DIGESTIVE ENZYMES: A WINDFALL OF MYCOPHAGY}

Whereas the previous Section dealt with some of the problems posed by the consumption of fungal tissue, this Section emphasizes a rather unusual benefit arising from mycophagy, namely, the acquisition of a set of fungal enzymes which extends the digestive capabilities of the consumer. Fungal enzymes acquired by consuming either fungal tissue or substrate into which fungal enzymes have been secreted may be essential to the digestive capabilities of many species. Those fungal enzymes which might benefit wood- or litter-feeding insects will be discussed first, followed by those which could aid species that feed predominantly upon fungal tissue. Then the possible ramifications of the acquisition of fungal phenol oxidases, enzymes involved in the metabolism of phenolic compounds and possibly in the degradation of lignin, will be explored. 


\section{(1) Enzymes active against plant cell-wall polysaccharides}

The higher fungi, especially the wood-rotting Basidiomycetes, produce copious quantities of enzymes active against cellulose (Zeller, r9r6; Bose \& Sarkar, I937; Gasciogne \& Gasciogne, I960; Lyr, I960, I964; Pourrat, Lamaison \& Pourrat, I975). Young growing mycelia are generally the most active in secreting extracellular cellulases (Lyr, I964), but the enzymes are also present in older mycelia and the tissues of fruiting bodies (Pourrat et al., 1975). Wood-rotting fungi also secrete enzymes active against other plant cell-wall polysaccharides, such as the hemicelluloses and pectin (Bose \& Sarkar, 1937; Lyr, I959 $a, b, c, d$, I963 $a$, 1964; Reese \& Shibata, 1965; Dekker \& Richards, 1975; Pourrat et al., 1975; Rexová-Benkovả \& Markovic, 1976).

The process by which xylophagous insects derive nourishment from wood has been a problem of long-standing interest to those investigating the nutrition and biochemistry of insects. The major structural components of wood, cellulose and lignin, are among the most digestion-resistant substances found in nature. Termites and beetles are the two groups which contain the largest number of xylophagous forms. Xylophagous beetles differ widely with respect to the efficiencies with which they digest the constituents of wood. The wood-boring larvae of some beetles, such as Lyctus sp. (Lyctidae) (Campbell, 1929) are apparently unable to digest the major structural polysaccharides of wood and must depend for nourishment upon the very limited quantities of starch and sugar which are present in the cambial regions and in the sapwood. Such species must, of course, consume very large quantities of wood to meet their nutritional requirements. Cell-wall components are utilized by other species, however. The larvae of some groups, such as the ambrosia beetles (Scolytidae and Platypodidae) and bark beetles (Scolytidae), appear to be able to degrade hemicellulose and pectin, but not cellulose (Hopf, r938; Parkin, I940; Baker, I963; Courtois, Chararas \& Debris, I96r ; Balogun, 1969, LeFay et al., 1970). Still other species, especially in the families Anobiidae and Cerambycidae, can degrade cellulose as well (Campbell, 1929; Falck, 1930; Muller, 1934; Norman, 1936; Becker, 1943; Spiller, 195I; Chararas, Echaubard \& David, I973). Gut enzymes active against cellulose have been detected in a number of xylophagous beetle larvae, particularly among the Cerambycidae (Ripper, I93I; Mansour \& Mansour-Bek, 1933, 1937; Muller, 1934; Parkin, 1940).

Many of the early studies of cellulose utilization by wood-boring beetles, doubtless influenced by Cleveland's classic investigation on termites (reviewed by Honigberg, r970) and Buchner's pioneering studies on endosymbiosis (Buchner, 1928), attributed cellulose digestion to endosymbiotic micro-organisms. However, subsequent investigations (Mansour \& Mansour-Bek, r934; Koch, 1962; Buchner, r965) have led to the view which prevails today that with a few exceptions (Rössler, I96r), the chief contribution of endosymbiotic micro-organisms to xylophagous beetle larvae is the provision of vitamins and possibly essential amino acids, and not of digestive enzymes. Thus, the source of gut enzymes active against cellulose and other cell wall polysaccharides is still not known, although it is often presumed that if they are not 
derived from gut micro-organisms then they must be secreted by the beetles themselves. An alternative hypothesis suggested in this review is that many of the enzymes present in the guts of xylophagous arthropods may be fungal enzymes acquired while feeding. The source may be fungal tissue itself or simply substrate into which fungal enzymes have been secreted. Fungal tissue has been observed along with wood fragments in the gut contents of a number of xylophagous species, including beetles (Savely, 1939), wood wasps (Francke-Grosmann, 1963; Morgan, 1968) and larval crane flies (Freeman, 1967).

Enzymes of fungal origin have been demonstrated in the digestive fluids of two fungus-feeders, the fungus-growing ant, Atta texana (Boyd \& Martin, I975 $b$ ), and the fungus-growing termite, Macrotermes natalensis (Macrotermitinae) (Martin \& Martin, 1978, 1979). Furthermore, in this latter species, it has been shown that cellulose digestion in the midgut can occur only if the acquired fungal enzymes are present. Along with the wood and other cellulosic materials derived from higher plants, these termites consume the conidiophores of a symbiotic fungus, Termitomyces sp., which they cultivate in their nests. All of the enzymes required for the digestion of cellulose, i.e. $C_{1}$-enzymes (active against crystalline cellulose), $C_{x}$-enzymes (active against non-crystalline cellulose and soluble derivatives or degradation products of cellulose), and $\beta$-glucosidases (active against cellobiose) are present in the termites' midguts. The termites' midgut epithelium and salivary glands produce $\mathrm{C}_{\mathbf{x}}$-enzymes and $\beta$-glucosidases, but no $C_{1}$-enzymes. The $C_{1}$-enzymes in the midgut are derived entirely from the fungal material included in the diet.

The decomposition of the leaves, twigs, branches and bark fragments which make up the litter layer of the forest floor comes about through the combined activities of micro-organisms and invertebrates. The prevailing view is that most of the actual chemical degradation of litter components is effected by fungi and bacteria, while the feeding activities of small invertebrates serve only to reduce the substrate to fragments of small size. However, it seems quite possible that litter-feeding invertebrates might augment their digestive capabilities through the acquisition of fungal enzymes, and that significant digestion of plant cell-wall components might occur in the guts of arthropods which feed upon litter. Fungal material has been identified in the gut contents of litter-feeding Collembola (Poole, 1959; Anderson \& Healey, 1972) and beetles (Dawson, 1965).

\section{(2) Enzymes active against fungal constituents}

Not only are chitin and non-cellulosic $\beta$-glucans the most common polysaccharides present in the cell walls of fungi, but in addition the enzymes required for the digestion of these same polysaccharides, namely chitinase (Jeuniaux, I963, I966) and $\beta$-D-(I,3)-glucanase (Reese \& Mandels, 1959), are common fungal enzymes. Within the fungal tissue, of course, substrate and enzyme are kept separate until the time in the growth or developmental cycle when the breakdown of old tissue is required in order to liberate materials needed for biosynthesis. However, the enzymes and their substrates would mix in an insect's gut following the mechanical disruption of the fungal tissue which would occur when the tissue was eaten. Thus, the con- 
clusion seems inescapable that insects which have a diet composed largely of fungal tissue obtain from their food, not only a set of potential nutrients, but many of the enzymes required for their digestion as well.

It is also intriguing to note that urease, the enzyme required for the liberation of urea nitrogen for use in protein synthesis, may be of general occurrence in higher fungi, including those fleshy agarics which contain urea (Cochrane, r958; Bonnet, 1959). Thus, it is even possible that invertebrates feeding upon the fruiting bodies of such fungi might gain access to the nitrogen reserves present in the urea through the activity of a fungal urease acquired along with the urea.

\section{(3) Enzymes active against phenolic substrates}

Fungi are sources of several classes of phenol-oxidizing enzymes, including tyrosinase $\left(\mathrm{O}_{2}: o\right.$-diphenol oxidoreductase $)$, laccase $\left(\mathrm{O}_{2}: p\right.$-diphenol oxidoreductase $)$, and peroxidase (donor: $\mathrm{H}_{2} \mathrm{O}_{2}$ oxidoreductase). Enzymatic activity is present in mycelia, rhizomorphs and fruiting bodies (Lindeberg, 1950; Lindeberg \& Holm, 1952; Lyr, 1956, Rösch, 1966). These enzymes are involved in the metabolism of phenolic compounds (Schubert, I965; Gibson, I968; Dagley, 1971; Rao, Nambudiri \& Bhat, I97I), and probably contribute to the detoxification of phenolic materials serving as defensive substances in wood (Lyr, $1962 a, b, 1963 b$, 1965; Mahedevan, 1974). It has also been proposed that they are involved in the degradation of native lignin and in the subsequent metabolism of the degradation products (Schubert, 1965; Kirk, 1971).

The lignin-degrading white-rot fungi secrete extracellular laccases (Lindeberg \& Holm, 1952; Luthardt \& Lyr, 1965), and sometimes peroxidases (Lyr, 1956), whereas the brown-rot fungi, which may alter but not decompose lignin, either do not produce or do not secrete these enzymes (Kaarik, 1965; Schubert, 1965; Kirk, 1971). The tyrosinases are intracellular enzymes produced by both white- and brown-rot fungi (Lindeberg \& Holm, r952; Luthardt \& Lyr, 1965).

Whether the acquisition of fungal tyrosinases and laccases would be of benefit to a wood- or fungus-feeding arthropod is problematical. It is not even certain that the enzymes would function in an insect's gut, since oxygen is the electron acceptor in the reactions catalysed by these oxidases, and it is not known whether the partial pressure of oxygen in an insect's gut is sufficient to sustain a significant amount of oxidation. However, since the guts of most insects do have a positive redox potential, indicative of oxidizing conditions (House, 1974 $b$ ), and since many insects are able to swallow air (Cottrell, I962), it seems quite likely that acquired fungal phenol oxidases would be able to function in the gut milieu. It is noteworthy in this regard that aromatic acids and phenols are degraded in the gut of the soil isopod, Oniscus asellus (Neuhauser \& Hartenstein, 1974). This transformation, which also requires oxygen, is carried out by ingested soil bacteria which survive for a time before being themselves digested (Kaplan \& Hartenstein, 1978).

Of the various processes in which fungal phenol oxidases are involved, detoxification would seem to be the one most likely to be useful to a xylophagous insect. Phenols occur widely in plant material, where they serve as defensive substances protecting the plant from insect and microbial attack (Levin, 197I; Beck \& Reese, I975). Just 
as the detoxification of heartwood phenols by fungal phenol oxidases allows fungal infection of heartwood ( $\mathrm{Lyr}, 1962 a, b$ ), so also the detoxification of such phenols would allow the consumption of heartwood by a xylophagous insect. Indeed, the detoxification system of a fungal pathogen, which has evolved to metabolize the specific set of defensive substance produced by its host, might be superior to the more general mixed-function oxidase system which serves as the primary metabolic mechanism in insects for detoxifying the defensive chemicals present in plants (Krieger, Feeny \& Wilkinson, 1971; Agosin \& Perry, 1974).

It is less clear whether degradation of lignin in an insect's gut, mediated by acquired fungal enzymes, would benefit the insect. Utilization of lignin as a supplementary source of energy requires not only that the lignin be degraded but also that the resulting phenolic degradation products be channelled into the tricarboxylic-acid cycle via protocatechuic acid and $\beta$-ketoadipate. If the degradation of lignin in the gut resulted only in the generation of an array of phenolic metabolites which were not metabolized further, then the process would accord no benefit to the insect. Indeed, it is even possible that some of the degradation products might be harmful. Clearly, the entire question of the implications to an arthropod of acquiring fungal phenol oxidases which might generate or metabolize phenolic substances in the gut is an interesting one, the clarification of which will require much additional research.

\section{(4) Requirements imposed by the exploitation of acquired digestive enzymes}

The preceding discussion has emphasized the benefits which can be derived from the acquisition of a set of digestive enzymes which expand the range of natural substrates that an organism can exploit as a nutrient source. It should also be recognized, however, that the exploitation of acquired digestive enzymes in turn imposes certain constraints and requirements upon the digestive system of the recipient. Certain conditions of the gut milieu, such as $\mathrm{pH}$, redox potential and ionic strength must be maintained at levels compatible with the requirements of the acquired enzymes. In addition, the degradation of the acquired enzymes by the recipient's own digestive proteinases must somehow be prevented or retarded.

The extracellular enzymes of fungi are generally rather stable enzymes, which are resistant to denaturation or deactivation under the conditions encountered in the substrate, and which are only slowly degraded by other proteolytic enzymes endogenous to the substrate or introduced by bacteria or other fungi. This stability of fungal enzymes is of obvious adaptive value to the fungus producing them. Possibly this inherent, evolved stability of fungal enzymes to the conditions encountered in the substrate might also result in their being sufficiently stable to the conditions encountered in the digestive tract of an insect consumer that they would survive long enough to perform a useful digestive function for the insect. However, it is also quite possible that the digestive systems of insects which benefit from the activities of acquired enzymes may have evolved in directions which foster the continued functioning of such enzymes.

Studies on the fungus-growing ants may provide a clue into one of the ways in which the recipients of fungal enzymes can maintain the activity of the enzymes in 
their guts (Boyd \& Martin, I975 $a, b$; Martin et al., 1975). The attine ants feed upon a fungus which they cultivate in their nests, and the fungal enzymes which they ingest remain active throughout the ants' digestive tract. In fact, the ingested fungal enzymes are still active in the ants' faecal fluid, which is deposited on the substrate being prepared for incorporation into the fungus garden. A careful examination of the proteinases present in the ants' digestive system revealed that they were all of fungal origin. It was not possible to detect any proteolytic enzymes produced by the ants. Thus, the ants avoid digesting the fungal enzymes through the simple expediency of not secreting any digestive proteinases of their own. Whether the deletion of digestive proteinases is a general trait of insects which exploit acquired digestive enzymes is a possibility which remains to be tested.

If the relationship between the fungus and its consumer is a mutualistic one, in which not only the consumer derives benefit from the acquisition of fungal enzymes but the fungus also profits from the spore-dispersing consequences of the consumer's feeding activities, then it is reasonable to expect that the fungus may have evolved characteristics which make it a particularly desirable food for its potential sporedispersal agents. Thus, fungi that produce enzymes which are unusually resistant to the action of insect proteinases may be favoured. In other words, just as higher plants enhance their attractiveness to potential seed-dispersal agents or pollinators by offerings of fruit and nectar, so also fungi might enhance their attractiveness to potential spore-dispersal agents by offerings of distinctive, stable, functional and mutually compatible, digestive enzymes.

\section{(5) Acquired digestive enzymes: a closing comment}

In this review the suggestion has been made that fungal enzymes, acquired either by feeding upon fungal tissue or upon a substrate into which the enzymes have been secreted, may augment the digestive capabilities of the organism acquiring them. Since fungi are excellent sources of stable enzymes active against the major constituents of plant and fungal tissue, the acquisition of fungal enzymes might be particularly useful to xylophagous and mycophagous insects. This hypothesis has emerged from a consideration of the nature of fungal enzymes, the circumstances under which the consumption of fungal tissue occurs, and the situations in which a useful role for the acquired fungal enzymes can be envisaged. The idea is a natural outgrowth of the author's interest in the fungus-growing ants and the fungus-growing termites, the latter group providing the single documented example of an acquired fungal enzyme contributing to the digestion of a component in the insect's diet. However, it should be quite evident that fungi are not the only possible source of enzymes which might be useful for another organism to acquire. It is quite possible that seeds, pollen, algae, plankton, and a host of other diverse types of food might provide digestive enzymes useful to the organisms which consume them. Therefore, this review will close with a general formulation of the hypothesis being advanced, namely, that strategies of resource utilization based upon the acquisition of the requisite digestive enzymes by the consumption of another organism or substrate may be of common occurrence. This is an hypothesis with significant biological 
implications, and it is the hope of the author that this review will stimulate investigations which will test its validity and generality.

\section{SUMMARY}

I. Fungal tissues have high nutritive potential. Although rather similar to foliage in their over-all nutrient make-up, fungal tissues and plant tissues are very different in terms of the chemical structures of many of their constituents.

2. The major structural polysaccharides of fungal cell walls are chitin and noncellulosic $\beta$-(I,3)- and $\beta$-(I,6)-glucans. Cellulose, lignin and pectin are absent. It is not known whether chitinase and $\beta$ - $(\mathrm{r}, 3)$ - and $\beta$-(r,6)-glucanases, the enzymes required for the digestion of the major fungal polysaccharides, occur widely in insects or not.

3. The most common fungal sterol is the 28 -carbon sterol, ergosterol. The capacity to utilize this sterol by removing the methyl group at $\mathrm{C}-24$ of the side chain, thereby converting it to a cholesterol derivative, is widespread among insects, including phytophagous species which do not normally consume fungal sterols.

4. Many fleshy fungi accumulate urea and ammonia in their fruiting bodies. It is not known whether mycophagous insects can utilize the nitrogen of dietary urea or ammonia for protein synthesis.

5. Fungi contain many secondary metabolites which doubtless play a role in determining host preferences in fungus-feeding species.

6. Fungi produce large amounts of several classes of enzymes which may continue to function in the gut of an insect which consumes fungal tissue or a substrate into which the fungal enzymes have been secreted.

7. Fungal enzymes acquired during feeding may contribute to the digestion of cellulose, hemicellulose and pectin in the guts of wood- and litter-feeding arthropods.

8. Fungal enzymes acquired during feeding may contribute to the digestion of chitin and non-cellulosic $\beta$-glucans in the guts of arthropods which feed on fungal sporophores or which otherwise restrict their diets largely to fungal material.

9. Fungal phenol oxidases acquired during feeding may augment an insect's capacities for detoxification.

\section{ACKNOWLEDGEMEN'T}

I thank Dennis F. Howard, Agnes I. Kiss, Jerome J. Kukor, Joan S. Martin, and Doyle B. McKey for their comments and criticisms of the first draft of this review.

\section{REFERENCES}

ACKerman, J. K. \& Shenefelt, R. D. (I973). Organisms, especially insects, associated with wood rotting higher fungi (Basidiomycetes) in Wisconsin forests. Transactions of the Wisconsin Academy of Sciences, Arts and Letters 61, $185^{-206 .}$

Agosin, M. \& Perry, A. S. (1974). Microsomal mixed-function oxidases. In The Physiology of Insecta, and ed., vol. 5 (ed. M. Rockstein), pp. 537-596. Academic Press, New York. 
Anderson, J. M. \& HeAley, I. N. (1972). Seasonal and inter-specific variation in major components of the gut contents of some woodland Collembola. Fournal of Animal Ecology 4r, 359-368.

Aronson, J. M. (1965). The cell wall. In The Fungi, vol. I (ed. G. C. Ainsworth and A. S. Sussman), pp. 49-76. Academic Press, New York.

Arpin, N. \& Fiasson, J. L. (I97I). The pigments of Basidiomycetes: their chemotaxonomic interest. In Evolution in the Higher Basidiomycetes (ed. R. H. Petersen), pp. 63-95. University of Tennessee Press, Knoxville.

BAKER, J. M. (1963). Ambrosia beetles and their fungi, with particular reference to Platypus cylindricus Fab. Symbiotic Associations, ${ }_{3}$ th Symposium of the Society for General Microbiology, London, pp. 232-265. University Press, Cambridge.

Balogun, R. A. (I969). Digestive enzymes of the alimentary canal of the larch bark beetle Ips cembrae Heer. Comparative Biochemistry and Physiology 29, 1267-1270.

BARRAS, S. J. \& PERRY, T. J. (1975). Interrelationships among microorganisms, bark or ambrosia beetles, and woody host tissue: an annotated bibliography, 1965-1974. U.S.D.A. Forest Service General Technical Report SO-го, I-34.

Barticicki-Garcia, S. (1968). Cell wall chemistry, morphogenesis and taxonomy of fungi. Annual Review of Microbiology 22, 87-108.

BARTNICKI-GARCIA, S. (I970). Cell wall composition and other biochemical markers in fungal phylogeny. In Phytochemical Phylogeny (ed. J. B. Harborne), pp. 81-103. Academic Press, New York.

BeCK, S. D. \& ReESE, J. C. (1975). Insect-plant interactions : nutrition and metabolism. Recent Advances in Phytochemistry ro, 41-92.

BECKER, G. (r942a). Untersuchungen über die-Ernährungsphysiologie der Hausbockkäfer-Larven. Zeitschrift für vergleichende Physiologie 29, 315-388.

BECKER, G. $(1942 b)$. Ökologische und physiologische Untersuchungen über die holzzerstörenden Larven von Anobium punctatum De Geer. Zeitschrift für Morphologie und Ökologie der Tiere 39, 98-I52.

BECKER, G. (1943). Zur Ökologie und Physiologie holzzerstörender Käfer. Zeitschrift für angewandte Entomologie 30, 106-1 18.

BENICK, L. (1952). Pilzkäfer und Käferpilze. Acta Zoologica Fennica 70, 1-250.

Birkinshaw, J. H. (1965). Chemical constituents of the fungal cell. 2. Special chemical products. In The Fungi, vol. I (ed. G. C. Ainsworth and A. S. Sussman), pp. 179-228. Academic Press, New York.

BLETChLEY, J. D. (1953). The influence of decay in timber on susceptibility to attack by the common furniture beetle, Anobium punctatum de G. Annals of Applied Biology 40, 21 8-221.

Bletchley, J. D. \& TAYloR, J. M. (1964). Investigations on the susceptibility of home grown Sitka spruce (Picea sitchensis) to attack by the common furniture beetle (Anobium punctatum de G.). Fournal of the Institute of Wood Science 12, 29-43.

BONNET, J. L. (1959). Application de la chromatographie sur papier a l'étude de diverse champignons. Bulletin de la Societé mycologique de France 75, 21 5-352.

Bose, S. R. \& SARKar, S. N. (1937). Enzymes of some wood-rotting polypores. Proceedings of the Royal Society of London $\mathrm{B}$ 123, I93-2 I3.

Boyd, N. D. \& Martin, M. M. (1975a). Faecal proteinases of the fungus-growing ant, Atta texana: properties, significance and possible origin. Insect Biochemistry 5, 619-635.

Boyd, N. D. \& Martin, M. M. (1975b). Faecal proteinases of the fungus-growing ant, Atta texana: their fungal origin and ecological significance. Fournal of Insect Physiology 2x, $1815-1820$.

Bracker, C. E. (1967). Ultrastructure of fungi. Annual Review of Phytopathology 5, 343-374.

BuChNER, P. (1928). Holznahrung und Symbiose. Springer: Berlin.

BuchNer, P. (1965). Endosymbiosis of Animals with Plant Microorganisms, Revised English Version. Interscience, New York.

Bursell, E. (1967). The excretion of nitrogen in insects. In Advances in Insect Physiology, vol. 4, (ed. J. W. L. Beament, J. E. Treherne and V. B. Wigglesworth), pp. 33-67. Academic Press, New York.

Buxton, P. A. (1960). British diptera associated with fungi. III. Flies of all families reared from about I 50 species of fungi. Entomologists' Monthly Magazine 96, 6I-94.

Camprell, W. G. (I929). The chemical aspects of the destruction of oak wood by powder rust and death watch beetles - Lyctus sp. and Xestobium sp. Biochemical fournal 23, I290-1 293. 
Chararas, C., Echaubard, M. \& David, J. (1973). Nutrition larvaire d'Ergates faber L. (Coleop. Cerambycidae): Morphologie du tube digestif, transit intestinal et consummation journalière Bulletin de la Societé zoologique de France $98,563-576$.

Clark, A. J. \& Bloch, K. (I959). Conversion of ergosterol to 22-dehydrocholesterol in Blattella germanica. Yournal of Biological Chemistry 234, 2589-2593.

Clayton, R. B. (1964). The utilization of sterols by insects. Fournal of Lipid Research 5, 3-19.

Clayton, R. B. (1970). The chemistry of nonhormonal interactions: terpenoid compounds in ecology. In Chemical Ecology (ed. E. Sondheimer and J. B. Simeone), pp. 235-280. Academic Press, New York.

Cochrane, V. W. (1958). Physiology of Fungi. John Wiley and Sons, New York.

CotTrRLl, C. B. (1962). General observations on the imaginal ecdysis of blowflies. Transactions of the Royal Entomological Society of London $114,317-333$.

Courtois, J. E., Chararas, C. \& Debris, M. M. (I96r). Recherches preliminaires sur l'attaque enzymatique des glucides par un coléoptère xylophage: Ips typographus. Bulletin de la Societé de Chemie biologique 43, $1173-1187$.

Cowling, E. B. \& Merrill, W. (1966). Nitrogen in wood and its role in wood deterioration. Canadian fournal of Botany 44, I539-1 554 .

Cromack, K., Todd, R. L. \& MoNk, C. D. (1975). Patterns of Basidiomycete accumulation in conifer and deciduous forest litter. Soil Biology and Biochemistry 7, 265-268.

Dagley, S. (197I). Catabolism of aromatic compounds by microorganisms. Advances in Microbial Physiology 6, $1-46$.

Dawson, N. (1965). A comparative study of the ecology of eight species of fenland Carabidae (Coleoptera). Fournal of Animal Ecology 34, 299-314.

DekKRR, R. H. F. \& RichaRos, G. N. (1975). Hemicellulases: their occurrence, purification, properties and mode of action. Advances in Carbohydrate Chemistry 32, 277-352.

Elton, C. S. (1966). The Pattern of Animal Communities. Methuen, London.

FAGER, E. W. (1968). The community of invertebrates in decaying oak wood. Fournal of Animal Ecology 37, $121-142$.

FALCK, R. (1930). Die Scheindestruktion des Koniferenholz durch die Larven des Hausbockes (Hylotrupes bajulus L.). Cellulosechemie II, 89-9I.

Fisk, F. W. \& RAO, B. R. (1964). Digestive carbohydrases in the Cuban burrowing roach. Annals of the Entomological Society of America 57, 40-44.

FITTECK, A. (1929). A study of the nitrogenous compounds in fungus tissue and their decomposition in the soil. Soil Science 27, $1-46$.

FoGEL, R. (1975). Insect mycophagy: a preliminary bibliography. U.S.D.A. Forest Service General Technical Report PNW-36, I-2r.

Foster, J. W. (1949). Chemical Activities of Fungi. Academic Press, New York.

Francke-Grosmann, H. (1939). Beitrage zur Kenntnis der Beziehungen unserer Holzwespen zu Pilzen. Proceedings of the 7 th International Congress of Entomology, Berlin, vol. 2, I120-1 137.

Francke-Grosmann, H. (1963). Some new aspects of forest entomology. Annual Review of Entomology 8, 415-438.

Francke-Grosmann, H. (1967). Ectosymbiosis in wood-inhabiting insects. In Symbiosis, vol. 2 (ed. S. M. Henry), pp. 142-205. Academic Press, New York.

Frezman, B. E. (1967). Studies on the ecology of larval Tipulinae (Diptera: Tipulidae). Fournal of Animal Ecology 36, 123-146.

Gasciogne, J. A. \& Gasciogne, M. M. (1960). Biological Degradation of Cellulose. Butterworths, London.

Gibson, D. T. (1968). Microbial degradation of aromatic compounds. Science, Washington I6r, I093I097.

Gorin, P. A. J. \& Spencer, J. F. T. (1968). Structural chemistry of fungal polysaccharides. Advances in Carbohydrate Chemistry 23, 367-417.

Graham, K. (1967). Fungal-insect mutualism in trees and timber. Annual Revierw of Entomology 12, $105 \rightarrow 126$.

Graves, R. C. (1960). Ecological observations on the insects and other inhabitants of woody shelf fungi. Annals of the Entomological Society of America 53, 61-78.

Hall, R. (1969). Molecular approaches to taxonomy of fungi. Botanical Reviews 35, 285-304. 
HeIm, R. (1977). Termites et Champignons. Doubee, Paris.

Heinemann, P. \& Casimir, J. (1960). Distribution des acides aminés libres dans le genre Agaricus Pr. sensu stricto (= Psalliota). Revue de Mycologie 29, 24-33.

Hodgman, C. D., Weast, R. C., Shankland, R. S. \& Selby, S. M. (1959). Handbook of Chemistry and Physics. Chemical Rubber Publishing Co., Cleveland.

Honigberg, B. (1970). Protozoa associated with termites and their role in digestion. In Biology of Termites, vol. 2 (ed. K. Krishna and K. M. Weesner), pp. I-36. Academic P1 ess, New York.

Hopf, H. S. (1938). Investigations into the nutrition of the ash bark beetle, Hylesinus fraxini Panz. Annals of Applied Biology 25, 390-405.

House, H. L. (1974a). Nutrition. In The Physiology of Insecta, and ed., vol. 5 (ed. M. Rockstein), pp. I-62. Academic Press, New York.

House, H. L. (1974b). Digestion. In The Physiology of Insecta, 2nd ed., vol. 5 (ed. M. Rockstein), pp. 63-1 7. Academic Press, New York.

INGLES, L. G. (1933). The succession of insects in tree trunks as shown by the collections from various stages of decay. Fournal of Entomology and Zoology, 25, 57-59.

Jeuniaux, C. (1963). Chitine et Chitinolyse, un Chapitre de la Biologie Moléculaire. Masson, Paris.

Jeuniaux, C. (1966). Chitinases. In Methods of Enzymology, vol. 8 (ed. E. F. Neufeld and V. Ginsburg), pp. 644-650. Academic Press, New York.

JEWELL, T. R. (1974). A quantitative study of cellulose distribution in Ceratocystis and Europhium. Mycologia 66, I 39-146.

KAARIK, A. (1965). The identification of the mycelia of wood-decay fungi by their oxidation reactions with phenolic compounds. Studia Forestalia Suecia 31, I-8o.

Kaplan, D. L. \& Hartenstein, R. (r978). Studies on monooxygenases and dioxygenases in soil macroinvertebrates and bacterial isolates from the gut of the terrestrial isopod, Oniscus asellus $\mathrm{L}$. Comparative Biochemistry and Physiology 6oB, 47-50.

KIRK, T. K. (1971). Effects of microorganisms on lignin. Annual Review of Phytopathology 9, 1852 I0.

Kitamoto, Y. \& GRUen, H. E. (1976). Distribution of cellular carbohydrates during development of the mycelium and fruitbodies of Flammulina velutipes. Plant Physiology 58, 485-491.

Косн, A. (1962). Grundlagen und Probleme der Symbioseforschung. Medizinische Grundlagenforschung 4, 63-I 56 .

KoK, L. T., Norris, D. M. \& CHU, H. M. (1970). Sterol metabolism as a basis for mutualistic symbiosis. Nature, London 225, 66I-662.

Krieger, R. I., FeENY, P. P. \& Wilkinson, C. F. (I97I). Detoxification enzymes in the guts of caterpillars: an evolutionary answer to plant defenses. Science, Washington I72, 579-581.

Larkin, P. A. \& Elbourne, C. A. (1968). Some observations on the fauna of dead wood in live oak trees. Oikos $\mathbf{1 5}, 79-92$.

Lawrence, J. F. (1973). Host preference in Ciid beetles (Coleoptera; Ciidae) inhabiting the fruiting bodies of Basidiomycetes in North America. Bulletin of the Museum of Comparative Zoology, Harvard University 145, 163-212.

LeFay, A., Courtois, J. E.,'Thuillier, A., Chararas, C. \& Lambin, S. (1970). Étude des oxidases de l'insecte xylophage Ips sexdentatus et sa flore microbienne. Annales de l'Institut Pasteur, Paris $\mathbf{r} \mathbf{9}$, $483-491$.

Levi, M. P. \& Cowling, E. B. (1969). Role of nitrogen in wood deterioration. VII. Physiological adaptation of wood-destroying and other fungi to substrate deficient in nitrogen. Phytopathology 59, $460-468$.

Levin, D. A. (1971). Plant phenolics: an ecological perspective. American Naturalist 105, 157I 8I.

Lewis, D. H. \& SMrTH, D. C. (1967). Sugar alcohols (polyols) in fungi and green plants. I. Distribution, physiology, and metabolism. New Phytologist 66, I43-184.

LiLly, V. G. (1965). Chemical constituents of the fungal cell. I. Elemental constituents and their roles. In The Fungi, vol. I (ed. G. C. Ainsworth and A. S. Sussman), pp. 163-177. Academic Press, New York.

Lindeberg, G. (I950). Phenoloxidases of the cultivated mushroom Psalliota bispora f. albida. Nature, London 166, 739 . 
LINDEBERG, G. \& HoLM, G. (1952). Occurrence of tyrosinase and laccase in fruit bodies and mycelia of some Hymenomycetes. Physiologia Plantarum 5, 100-1 I4.

LiNDQUisT, E. L. (1970). Relationships between mites and insects in forest habitats. Canadian Entomologist 102, $978-984$.

LINDQUIST, E. L. (1975). Associations between mites and other arthropods in forest floor habitats. Canadian Entomologist 107, 425-437.

LuthaRDT, W. \& LYR, H. (1965). Uber die Bildung von Tyrosinase bei holzzerstörenden Pilzen. Archiv fïr Mikrobiologie 51, 103-117.

LYR, H. (1956). Untersuchungen über die Peroxidasen höheren Pilze. Planta 48, 239-265.

LYR, H. (1959a). Die Bildung von Ektoenzymen durch holzzerstörende und holzbewohnende Pilze auf verschiedenen Nährboden. Archiv für Microbiologie 33, 266-282.

LYR, H. (1959b). Die Bildung von Ektoenzymen durch holzzerstörende und holzbewohnende Pilze auf verschiedenen Nährboden. Archiv für Mikrobiologie 34, I 89-203.

LYR, H. (1959c). Die Bildung von Ektoenzymen durch holzzerstörende und holzbewohnende Pilze auf verschiedenen Nährboden. Archiv für Mikrobiologie 34, 238-250.

LYR, H. (I959d). Die Bildung von Ektoenzymen durch holzzerstörende und holzbewohnende Pilze auf verschiedenen Nährboden. Archiv für Mikrobiologie 34, 418-433.

LYR, H. (1960). Die Bildung von Ektoenzymen durch holzzerstörende und holzbewohnende Pilze auf verschiedenen Nährboden. Archiv. für Mikrobiologie 35, 258-278.

LYR, H. (1962a). Enzymatische Detoxification der Kernholztoxine. Flora 152, 570-579.

LXR, H. (1962b). Detoxification of heartwood toxins and chlorophenol by higher fungi. Nature, London I95, 289-29o.

LYR, H. (1963a). Uber das Vorkommen von Mannase bei Pilzen. Zeitschrift für allgemeine Microbiologie $3,25-36$.

LYR, H. (1963b). Enzymatische Detoxification chlorierter Phenole. Phytopathologische Zeitschrift 47, 73-83.

LYR, H. (1964). Alterung und Enzymbildung bei höheren Pilzen. Zeitschrift für allgemeine Mikrobiologie 4, 249-258.

LYR, H. (1965). On the toxicity of oxidized polyphenols. Phytopathologische Zeitschrift 52, 229-240.

MaHEDevan, A. (1974). Detoxification mechanisms of plant pathogens. Fournal of Scientific and Industrial Research 33, I31-1 38.

Mansour, K. \& Mansour-BeK, J. J. (I933). On the digestion of wood by insects. Fournal of Experimental Biology II, 243-256.

MANSOUR, K. \& MANSOUR-BEK, J. J. (1934). The digestion of wood by insects and the supposed role of micro-organisms. Biological Reviews 9, 363-382.

Mansour, K. \& Mansour-BeK, J. J. (1937). On the cellulase and other enzymes of the larvae of Stromatium fulvum Villers (Family Cerambycidae). Enzymologia 4, I-6.

Martin, M. M., Boyd, N. D., Gieselmann, M. J. \& Silver, R. G. (1975). Activity of faecal fluid of a leaf-cutting ant toward plant cell wall polysaccharides. Fournal of Insect Physiology 21, 1887-1 892.

Martin, M. M., Gieselmann, M. J. \& Martin, J. S. (1973). Rectal enzymes of attine ants, $\alpha$-Amylase and chitinase. Fournal of Insect Physiology 19, 1409-1416.

Martin, M. M., Gieselmann, M. J. \& Martin, J. S. (1976). The presence of chitinase in the digestive fluids of ants. Comparative Biochemistry and Physiology 53 A, 331-332.

Martin, M.M. \& Martin, J. S. (1978). Cellulose digestion in the midgut of the fungus-growing termite, Macrotermes natalensis: the role of acquired digestive enzymes. Science, Washington 199, I453-I 455 .

Martin, M. M. \& Martin, J. S. (1979). The distribution and origins of the cellulolytic enzymes of the higher termite, Macrotermes natalensis. Physiological Zoology 52 (in Press).

Matthewman, W. G. \& PIrlou, D. P. (197I). Arthropods inhabiting the sporophore of Fomes fomentarius (Polyporaceae) in Gatineau Park, Quebec. Canadian Entomologist 103, 775-847.

Merrill, W. \& Cowling, E. B. (1966). Role of nitrogen in wood deterioration: amount and distribution of nitrogen in fungi. Phytopathology 56, 1083-1090.

MrLAzzo, F. A. (1965). Sterol production by some wood-rotting Basidiomycetes. Canadian foumal of Botany 43, 1347-r 353 .

Milner, M. W. (I961). The Pfizer Handbook of Microbial Metabolites. McGraw-Hill, New York. 
Morgan, F. D. (1968). Bionomics of Siricidae. Annual Review of Entomology 13, 239-256.

MoRgan, M. R. J. (1975). A qualitative survey of the carbohydrases of the alimentary tract of the migratory locust, Locusta migratoria migratorioides. Fournal of Insect Physiology 21, 1045-1053.

Moser, J. C. \& Roton, L. M. (197I). Mites associated with southern pine bark beetles in Allen Parish, Louisiana. Canadian Entomologist ro3, 1775-1 798.

Muller, W. (1934). Untersuchungen über die Symbiose von Tieren mit Pilzen und Bakterien. Archiv für Mikrobiologie 5, 84-147.

Neuhauser, E. \& Hartenstein, R. (1976). Degradation of phenol, cinnamic and quinic acid in the terrestrial crustacean Oniscus asellus. Soil Biology and Biochemistry 8, 95-98.

Norman, A. G. (1936). The destruction of oak by the death watch beetle. Biochemical fournal 30, I 135 -I 137 .

NorrIs, D. M. (1972). Dependence of fertility and progeny development of Xyleborus ferrugineus upon chemicals from its symbionts. In Insect and Mite Nutrition (ed. J. G. Rodriguez), pp. 299-3ro. North-Holland, Amsterdam.

PARKIN, E. A. (I940). The digestive enzymes of some wood-boring beetle larvae. Fournal of Experimental Biology r7, 364-377.

Parkin, E. A. (1942). Symbiosis and siricid woodwasps. Annals of Applied Biology 29, 268-274.

Paviour-Smith, K. (I $960 a$ ). The fruiting-bodies of macrofungi as habitats for beetles of the family Ciidae (Coleoptera). Oikos II, 43-7I.

Paviour-Smitr, K. (1960b). Insect succession in the 'birch bracket fungus', Polyporus betulinus. Proceedings of the $\mathrm{I}$ th International Congress of Entomology, Vienna, vol. 1, 792-796.

Presou, D. P. (1966). The fauna of Polyporus betulinus (Bulliard) Fries (Basidiomycetes: Polyporaceae) in Gatineau Park, Quebec. Canadian Entomologist 98, 1233-1237.

Pielou, D. P. \& Verma, A. N. (1968). The arthropod fauna associated with the birch bracket fungus, Polyporus betulinus, in Eastern Canada. Canadian Entomologist roo, $1179-1199$.

Pilat, R. \& ǓsaK, O. (I 958). Mushrooms. Spring Books, London.

Poole, T. B. (1959). Studies on the food of Collembola in a Douglas fir plantation. Proceedings of the Zoological Society of London 132, 71-82.

Ports, R. C. \& Hewitr, P. H. (1974). The partial purification and some properties of the cellulase from the termite Trinervitermes trinervoides (Nasutitermitinae). Comparative Biochemistry and Physiology 47 B, 317-326.

Pourrat, H., Lamaison, J. L. \& Pourrat, A. (1975). Activités cellulolytiques des Macromycètes. Annales pharmaceutiques franfais 33, 495-504.

Powning, R. F. \& Irzykiewicz, H. (I963). Chitinase from the gut of the cockroach, Periplaneta americana. Nature, London 200, II 28.

Proudfit, F. T. \& Robinson, C. H. (1961). Normal and Therapeutic Nutrition. McMillan, New York.

Rao, P. V. S., Nambudiri, A. M. D. \& Bhat, J. V. (I971). Microbial degradation of phenylpropanoid compounds. Fournal of Scientific and Industrial Research 30, 663-679.

RAST, D. (1965). Zur stoffwechselphysiologischen Bedeutung von Mannit und Trehalose in Agaricus bisporus. Planta 64, 81 -93 .

Reese, E. T. \& Mandels, M. (1959). $\beta$-D-(1,3)-Glucanases in fungi. Canadian Yournal of Microbiology $5,173-185$.

Reese, E. T. \& Shibata, Y. (1965). $\beta$-Mannanases of fungi. Canadian fournal of Microbiology II, $167-183$.

ReHFous, M. (1955). Contribution à l'étude des insectes des champignons. Mitteilung der Schwerische Entomologische Gesellschaft 28, 1-106.

Rexova-Benkova, L. \& Markovic, O. (1976). Pectic enzymes. Advances in Carbohydrate Chemistry 33, $323-385$.

RIPPER, W. (I93I). Zur Frage des Celluloseabbaus bei der holzverdauung xylophager Insektenlarven. Zeitschrift für vergleichende Physiologie 13, 314-333.

Robbins, W. E., Kaplanis, J. N., Svoboda, J. A. \& Thompson, M. J. (1971). Steroid metabolism in insects. Annual Review of Entomology 16, 53-72.

RohrmanN, G. R. (1978). The origin, structure, and nutritional importance of the comb in two species of Macrotermitinae (Isoptera: Termitidae). Pedobiologia (in the press).

Rösch, R. (1966). Über die intracellularen Polyphenoloxidasen der Bräunfaulepilze. Archiv für Mikrobiologie 54, 80-90. 


\section{Insect mycophagy}

Rosenthal, G. A., Janzen, D. H. \& Dahlman, D. L. (1977). Degradation and detoxification of canavanine by a specialized seed predator. Science, Washington $\times 96,658-660$.

RőssLER, M. E. (196I). Ernährungsphysiologische Untersuchungen an Scarabaeidenlarven (Oryctes nasicornis L., Melolontha melolontha L.). Fournal of Insect Physiology 6, 62-80.

Sands, W. A. (1969). The association of termites and fungi. In Biology of Termites, vol. I (ed. K. Krishna and F. M. Weesner), pp. 495-524. Academic Press, New York.

SavkLY, H. E. (1939). Ecological relationships of certain animals in dead pine and oak logs. Ecological Monographs 9, 321-385.

SAXENA, S. C. \& SARIN, K. (1972). Chitinase in the alimentary tract of the lesser mealworm, Alphitobius diaperinus (Panzer) (Coleoptera: Tenebrionidae). Applied Entomology and Zoology 7, 94.

ScherRPELtz, O. \& Höfler, K. (1948). Käfer und Pilze. Verlag für Jugend und Volk, Wien.

SCHUBert, W. J. (1965). Lignin Biochemistry. Academic Press, New York.

SEDEE, P. D. J. W. (1958). Dietary requirements and intermediary protein metabolism of an insect (Calliphora erythrocephala Meig.). Entomologia experimentalis et applicata 1, 38-40.

Singer, R. (196r). Mushrooms and Truffles. Interscience, New York.

SPILLER, D. (1951). Digestion of alpha-cellulose by larvae of Anobium punctatum De Geer. Nature, London 168, 209-210.

StARK, N. (1972). Nutrient cycling pathways and litter fungi. Bioscience 22, 355-360.

StBin von KAMIENSKI, E. (1958). Untersuchungen über die flüchtigen amine der Pflanzen. III. Die Amine von Pilzen. Úber den Weg der Aminbildung in Pflanzung. Planta 50, 331-352.

Thatcher, F. S. (1954). Foods and feeds from fungi. Annual Review of Microbiology 8, 449-472.

Tyler, V. E., Benedict, R. G. \& Stuntz, D. E. (1965). Chemotaxonomic significance of urea in the higher fungi. Lloydia $28,342-353$.

VAN LEAR, D. A. \& GoEBEL, N. B. (1976). Leaf fall and forest floor characteristics in loblolly pine plantations in South Carolina Piedmont. Fournal of the Soil Science Society of America 40, 116-119.

Wallace, H. R. (1953). The ecology of insect fauna of pine stumps. Fournal of Animal Ecology 22, I54-17I.

Waterhouse, D. F. \& McKrllaR, J. W. (196r). The distribution of chitinase activity in the body of the American cockroach. Journal of Insect Physiology 6, I85-195.

WEBER, N. A. (1972). Gardening ants: the attines. Memoirs of the American Philosophical Society 92, $1-146$.

Weiss, H. B. (1920). The insect enemies of polyporoid fungi. American Naturalist 54, 443-447.

WheELER, W. M. (I907). The fungus-growing ants of North America. Bulletin of the American Museum of Natural History 23, 669-807.

WhitAKER, D. R. (1951). Studies in the biochemistry of cellulolytic micro-organisms. r. Carbon balances of wood-rotting fungi in surface cultures. Canadian foumal of Botany 29, 159-175.

ZELLER, S. M. (1916). Studies in the physiology of the fungi. II. Lenzites saepiaria Fries, with special reference to enzyme activity. Annals of the Missouri Botanical Garden 3, 439-509. 